Digitalizacja archiwalnych numerów czasopisma naukowego Analecta Cracoviensia 1-24 (1969-1992) i ich publikacja w otwartym dostępie - zadanie finansowane w ramach umowy 672/P-DUN/2017 ze środków Ministra Nauki i Szkolnictwa Wyższego przeznaczonych na działalność upowszechniającą naukę

\title{
PSYCHOLOGICZNE ASPEKTY CIERPIENIA
}

Fakt, problem i tajemnica cierpienia niepokoją ludzkość od zarania jej istnienia. Dzięki świadomości i zdolności do stawiania pytania o sens w horyzoncie wartości pozabiologicznych człowiek nie tylko odczuwa ból i cierpi, ale próbuje też zrozumieć swoje doświadczenia. Cierpienie ludzkie opisuje się w rozmaity sposób w zależności od typu nauki. Medycyna np. bardziej interesuje się fizjologicznymi korelatami cierpienia, koncentrując uwagę na szeregu działań, których celem ma być eliminowanie bólu. Filozofowie włączają cierpienie w nurt refleksji o kondycji człowieka, jako niedoskonałości, losie, itp. W zależności od przyjmowanych tez antropologicznych badacze uznają jego wartość lub totalny absurd (bezsens). Teologia z kolei wyznacza najszerszą perspektywę widzenia ludzkiego cierpienia, bowiem ukazuje jego tajemnicę. Zarazem jednak wskazuje na fakt, że cierpienie zostało odkupione przez cierpienie Boga-Człowieka i dlatego nie może być bagatelizowane.

Oddalając się od filozofii i teologii, tzw. psychologia naukowa nie znajdowała miejsca na pogłębioną refleksję o cierpieniu, a niektóre jej kierunki (behavioryzm) cierpienie sprowadzały jedynie do jakiejś formy reakcji. Z drugiej strony osiągnięcia rozmaitych odmian psychoanalizy przekonały badaczy, że od ludzkiego istnienia nieodłączne są rozmaite negatywne doświadczenia (stresy, konflikty, kryzysy) a nawet tragedie osobowościowe (zaburzenia i choroby psychiczne), które wyrosły z cierpienia bądź rodzą cierpienie. Ogromny wysiłek niesienia pomocy, jaki podejmuje się w psychoterapii, jest pośrednią akceptacją prawdy o nieuniknioności cierpienia. Powszechność cierpienia próbował przed laty wyjaśnić jeden z inspiratorów myślenia egzystencjalno-humanistycznego w psychologii - K. Jaspers przez opis cierpienia jako fundamentalnej sytuacji granicznej, a za nim poszedł twórca III Wiedeńskiej Szkoły Psychoterapii - V.E. Frankl. Rozumowanie tego uczonego, wyrosłe z własnych doznań w obozie zagłady, współbrzmi z nauczaniem doświadczonego przez cierpienie Jana Pawła II.

Niniejszy artykuł należy traktować jako wprowadzenie do psychologicznej refleksji o cierpieniu. Będzie w nim mowa jedynie o genezie, rodzajach i funkcjach cierpienia. 
Słowo cierpienie należy do terminów nieostrych. jego rozumienie zależy bowiem od tego, co się w danym okresie historycznym myśli na temat człowieka, jakie jest wartościowanie życia w ogóle, jaki jest tzw. duch epoki. Jest oczywiste, że konceptualizowanie cierpienia łączy się także z typem nauki, w ramach której prowadzi się nad nimi refleksję. Stąd też np. filozofowie, szczególnie egzystencjalni, wielokrotnie piszą o cierpieniu, natomiast medycyna chętniej używa słowa choroba czy ból. Frankl zwraca uwagę, że jednostronne podejście do człowieka, wyrażające się nihilistycznym biologizmem, fizjologizmem, psychologizmem czy socjologizmem znajduje swoje reperkusje w zaniechaniu refleksji o cierpieniu człowieka, o jego sensie oraz ofiarniczej i ekspijacyjnej roli, jaką może spełniać w życiu jednostki ludzkiej.

Cierpienie może być uznawane za cechę wspólną dla wszystkich ludzi ${ }^{1}$, bowiem towarzyszy ono - niezależnie od tego, jak specyficzna jest konstelacja cech osobowościowych jednostki - każdemu człowiekowi w różnych fazach jego rozwoju (urodziny, konflikty i problemy dojrzewania, umieranie), refleksja nad nim jest częścią światopoglądu i systemów religijnych. Cierpienie zaznacza swoją obecność niezależnie także od statusu ekonomiczno-społecznego. Aczkowiek status materialny ma znaczenie w podejmowanych formach walki z cierpieniem (np. dla bogatszego bardziej dostępne są środki medyczne), to jednak poczucie osamotnienia i poszukiwanie sensu w cierpieniu są ostatecznie niezależne od tego, co człowiek posiada. Cierpienie osoby jest jednak inne od doznań pozostałych istot świata przyrody ożywionej. Istotną rolę odgrywa tutaj świadomość i możliwość antycypacji zdarzeń, w jakich osoba może uczestniczyć. To sprawia, że cierpienie może być nazwane zhumanizowanym bólem. Nieco patetycznie i nie zawsze adekwatnie nazywa się je bólem duszy.

Kielanowski ${ }^{2}$ zauważa, że w lekarskich tekstach i języku codziennym takie schorzenia jak gruźlica, rak, migrena, schizofrenia to choroby a nie cierpienie. Przed kilkudziesięciu laty jednak określenie cierpienie było stosowane jako synonim choroby (fr. souffrance, ang. suffering, niem. Leiden). Greckie paschein, łac. sustinere czy staropolskie cierzpieć nie oznacza tylko bólu, przykrości, lecz również świadomość podlegania czemuś, co jest narzucone.

Cierpienie jest stanem złożonym, wielowymiarowym, często niedostępnym nawet dla najbardziej wyrafinowanych ujęć medycznych. Choć między bólem a cierpieniem zachodzą wielorakie korelacje, to jednak istotne jest, że cierpienie łączy się z uczuciami wyższymi. Generalnie trzeba powiedzieć, że cierpienie jest bardziej podstawowe od choroby, bo głębiej osadza się w czło-

${ }^{1}$ Por. J. Szczepańs ki, Sprawy ludzkie, Warszawa 1980, s. 9-12.

${ }^{2}$ Cztowiek, jego ból, cierpienie i prawo do szczęścia, Gdańsk 1980, s. 17 - 18. 
wieczeństwie. Pierwiastek duchowy człowieka jest bezpośrednim podmiotem cierpienia ${ }^{3}$.

Pisząc o genezie cierpienia można mieć na uwadze przynajmniej dwie sprawy: świadomość tego, co doprowadziło do cierpienia (tj. rozmaite czynniki chorobotwórcze i czynniki etiologiczne bólu), bądź szukać powiązania cierpienia z kondycją czlowieka. Na ten ostatni aspekt zwracają uwagę filozofujący psychologowie i psychiatrzy, którzy dokonują pewnych uogólnień nt. człowieka i jego sposobów istnienia. Czołowy przedstawiciel psychologii i filozofii sensu - V.E. Frankl, zastanawiając się nad losem ludzi, pisze, że „istotnym przeznaczeniem człowieka jest cierpieć: być homo patiens" 4 . Spojrzenie w głąb istnienia człowieka ujawnia tragiczność losu ludzkiego, ale z drugiej strony nie musi być tak, aby to przerażało ${ }^{5}$. Istnieje bowiem możliwość usensownienia cierpienia. Jakby nawiązując do starej już koncepcji, że życie łączy się ź ruchem, przedstawicielka medycyny zauważa, że cierpienie sygnalizuje, iż mamy do czynienia z człowiekiem aktywnym. Od cierpienia mógłby uwolnić „tylko całkowity bezruch, a więc bezistnienie" 6 .

Cierpienie ma charakter koniecznościowy, ponieważ życie człowieka jako bytu stającego się - decyduje również o otwartości na cierpienie, którego rachunek spełni się dopiero w przyszłości pozaziemskiej. Słowa Frankla, że „rachunek cierpiącego zakończy się dopiero $w$ transcendencji, w immanencji pozostaje otwarty"7 oznaczają z jednej strony prawdę o dynamice osoby ludzkiej, a z drugiej wskazują na bliskie powiązania tej myśli z doświadczeniem chrześcijańskim, inaczej mówiąc - personalistyczną wizją człowieka, według której wszystko, co się zdarza w świecie empirycznym ma dopełnienie — przez fakt zaciągania winy lub odnoszenia sukcesu i poczucia satysfakcji - w wymiarze transcendentnym.

Analizując rodzaje cierpienia, należy też wskazać, że można mówić o pasywnym i aktywnym cierpieniu, a tym samym o wielu problemach psychologicznych, jakie pojawiają się w odmiennych sytuacjach, $\mathrm{tj}$. zadawania cierpienia i bycia adresatem (przemiotem) cierpienia. Jednakże pod względem psychologicznym najbardziej interesująca jest analiza struktury i uwarunkowań procesu cierpienia. Bogaty w psychologiczną refleksję papieski dokument o cierpieniu zwraca uwagę, że jest to „owa wieloraka i podmiotowo zróżnicowana 'aktywność' bólu, smutku, zawodu, przygnębienia czy wręcz rozpaczy — zależnie od intensywności cierpienia, od jego głębi, pośrednio zaś od całej struktury cierpiącego podmiotu, od jego specyficznej wrażliwości. Pośrodku tego wszys-

3 „Salvifici doloris” - List Apostolski Ojca Świętego Jana Pawta II o chrześcijańskim sensie ludzkiego cierpienia, Watykan 1984. W dalszej części artykułu będzie on cytowany w skrócie SD wraz z podaniem numeru paragrafu.

${ }^{4}$ Homo patiens, Warszawa 1984 , s. 77.

${ }^{5}$ Por. K. J a s pe rs, Filozofia egzystencji, Warszawa 1990, s. 375.

${ }^{6}$ K. O si ń s k a, Twórcza obecność chorych, Warszawa 1983, s. 17.

${ }^{7}$ Homo patiens, s. 126. 
tkiego, co stanowi psychologiczny kształt cierpienia, tkwi zawsze jakieś doznanie zła, z powodu którego człowiek cierpi" 8 . Z powyższego tekstu wynika m.in. prawda, że rozmaite rodzaje i poziomy cierpienia mają ostatecznie aspekt aksjologiczny, a to oznacza, że bez właściwej wizji człowieka i jego misji w świecie nie jest możliwe humanistyczno-psychologiczne traktowanie cierpienia. Papieski tekst sugeruje również osobowościowe zróżnicowania stosunku do cierpienia w zależności od tego, jak ono jest doświadczane i kim pod względem psychicznym jest osoba stanowiąca podmiot tegoż doświadczenia. Jest to zagadnienie odrębne i przedstawię je w innym opracowaniu. Tutaj jedynie zauważę, że w rozumowaniu nt. cierpienia musi się wyjść poza wszelkie szczególowe opisy fenomenologiczno-psychologiczne, aby ustrzec się rażących uproszczeń.

Jeżeli zgodzimy się z opinią, że tyle jest rodzajów cierpienia, ile jest osób, spośród których każda ma określoną historię własnego życia, a także specyficzną (niepowtarzalną) konstelację cech własnej osobowości, to również musimy zauważyć, iż niezmiernie trudno jest przybliżyć istotę doświadczenia cierpienia. Wydaje się jednak, że biorąc pod uwagę poszczególne aspekty (wymiary) istnienia człowieka, daje się wymienić zasadnicze rodzaje cierpienia. Podstawowym kryerium typologizacji cierpienia może być obszar dóbr, funkcji, wartości, jakie narusza doświadczenie zła kojarzonego z nim najczęściej. Tutaj nadmieńmy, że niekoniecznie cierpienie do końca jawi się jako zło, wręcz przeciwnie - w wielu przypadkach, zwłaszcza u osób religijnych, cierpienie początkowo widziane jako przejaw inwazji jakiegoś wrogiego czynnika i dezintegracji organizmu, po jakimś czasie nabiera mniejszej lub większej wartości. Staje się okazją do dania świadectwa, drogą ekspijacji, itp. Cierpienie naruszające strukturę fizyczną człowieka, i tym samym jego fizjologiczne funkcjonowanie, nazywane jest bólem fizycznym. Na tym poziomie cierpienie powstaje wskutek zaburzenia wewnętrznej homeostazy organizmu. kiedy zaś brak homeostazy dosięgnie psychicznego wymiaru osoby, wówczas mówimy o cierpieniu psychicznym. Ma ono rozmaite odcienie i jest precyzyjnie opisywane w diagnostyce nozologicznej. Ze względu na teoretyczny charakter niniejszego opracowania nie wymieniam wszystkich przejawów cierpienia psychicznego i odsyłam w tym miejscu do bardzo dobrych opisów udręk psychicznych, jakie zawierają prace A. Kępińskiego. Ten wybitny psychiatra krakowski rozumiał, że bardziej cierpi ten, kto więcej czuje i inaczej rozumie ${ }^{9}$.

Ból ducha czy boleść duszy to poetyckie określenia cierpienia duchowego. Odrzucana przez niektóre systemy filozoficzno-psychologiczne prawda o istnieniu nieśmiertelnej duszy zaowocowała także zaniechaniem refleksji nad doznaniami duchowymi. Uważano nieco pogardliwie, że sprawy ducha to mrzon-

${ }^{8} \mathrm{SD}, \mathrm{nr} 7$.

9 Schizofrenię - jedno z głównych swych dzieł - zadedykował „tym, którzy więcej czują i inaczej rozumieją i dlatego bardziej cierpią, a których często nazywamy schizofrenikami”. 
ki i owoc iluzorycznego nastawienia do świata. Jednakże krzykliwe próby zagłuszenia ducha nie przyniosły oczekiwanych wyników, bowiem odrodziła się myśl psychologiczna, według której cierpienie duchowe „nie jest czymś chorobliwym, ale czymś najbardziej ludzkim ze wszystkiego, co istnieje"10. Taka doniosłość cierpienia duchowego wynika stąd, że rodzi się ono na styku z wartościami najwyższym, wobec których niewierność rodzi lęk i cierpienie moralne.

Cierpienie fizyczne dotyczy sfery wrażeń. Aby ono miało miejsce, musi zadziałać jakiś konkretny bodziec, który odbiorą zmysły zewnętrzne lub wewnętrzne. W zespole cierpień fizycznych odnajdujemy więc głód, ból, chłód, ale także inne zaburzenia, które genetycznie i funkcjonalnie łączą się ze sferą somatyczną. Najczęściej jednak przejawiają się one w zaburzeniach zdrowia, dolegliwościach czy tzw. stanach chorobowych. Cierpienie fizyczne wynika więc z dolegliwości ludzkiego organizmu, które są powodowane czynnikami wewnętrznymi (endogennymi) bądź zewnętrznymi (egzogennymi). W pierwszym przypadku farmakologicznie, biochemicznie i hormonalnie uwarunkowane nieprzyjemne wrażenia ustrojowe syngalizowane są w formie odczucia głodu, pragnienia, snu. Są reakcją na jakiś deficyt. Źródłem cierpienia fizycznego zewnętrznego są wrażenia odbierane z otaczającego środowiska.

Analiza cierpienia fizycznego odsyła nas do problematyki bólu. Ból jest także pojęciem wieloznacznym, choć najczęściej kojarzonym ze swoistym sygnałem ostrzegawczym, jakim dysponuje organizm w celu samoobrony (zachowania homeostazy). W literaturze spotyka się koncepcje zrozumienia bólu jako synonimu cierpienia w najogólniejszym znaczeniu ${ }^{11}$. Zwraca się też uwagę, że ból jest genetycznie pierwotniejszy, złączony z samym procesem tworzenia się życia, podobnie jak emocje, a cierpienie, analogicznie do uczuć ma charakteryzować człowieka ${ }^{12}$. Wydaje się, że niektóre kontrowersje dotyczące bólu i jego relacji do cierpienia dają się uporządkować przez odróżnienie bólu prawidłowego, czyli uczucia organicznego, i bólu patologicznego. Ten ostatni rodzaj bólu miałby znacznie bliższe powiązania z cierpieniem, gdyż trwa dłużej aniżeli powodujący go czynnik ${ }^{13}$. Ból u człowieka jest nową jakością ze względu na wzajemne powiązanie sfery biosu z psyche. Stąd też nie zawsze udaje się precyzyjnie pokazać, gdzie jest granica między bólem — jako sygnałem niebezpieczeństwa dla organizmu - a cierpieniem - jako wezwaniem do poszukiwania sensu własnej egzystencji. W reakcjach na ból wyróżnia się — obok reakcji wegetatywnej, ruchowej i hormonalnej - tzw. reakcję psychiczną. Przejawia się ona w zależności od typu osobowości np. jako zwiększona wrażliwość na ból i szereg reakcji psychoruchowych.

${ }^{10}$ Homo patiens, s. 15.

${ }^{11}$ Por. T. M. Domżał, Ból, Warszawa 1980, s. 7.

12 Zob. W. Szew czu k, Osobowościowy aspekt bólu, [w:] T. Kielanowski (red.) Człowiek, jego ból, cierpienie i prawo do szczęścia, Gdańsk 1980, s. 301.

${ }^{13}$ Por. T. M. Domżał, Ból, s. 103. 
Cierpienie psychiczne jest możliwe dlatego, że człowiek dysponuje wyobraźnią, uczuciami, świadomością, zdolnością do pytania o sens i myśleniem holistycznym. Podobnie jak w przypadku cierpienia fizycznego, jest ono odniesione ostatecznie do jakiegoś zła lub niedostatku dobra, którego człowiek pragnął. Widać w tym miejscu, jak wielką rolę odgrywa w cierpieniu psychicznym parametr czasu, dzięki któremu jest możliwa antycypacja, i wspomnienia. Cierpieniu powodowanemu przez czynniki psychiczne towarzyszy też lęk i zwykle depresja, która „,jest nierozwiązalnym stanem smutku i cierpienia”14.

W kontekście analizy cierpienia psychicznego pisze się też o autentycznym, o fałszywym cierpieniu oraz o cierpieniu neurotycznym. Zdaniem C. G. Junga cierpienie fałszywe pojawia się na tle nerwicowym, a cierpienie prawdziwe jest nieodzowne do uzyskania dojrzałości ${ }^{15}$. Zatem kryterium odróżniania cierpienia autentycznego od fałszywego jest jego geneza i funkcja. To, co Jung zaproponował, ma także znaczenie w kontekście szerszym. Chodzi mianowicie o tzw. cierpienie neurotyczne i cierpienie normalne, a więc adekwatne do zastanej sytuacji. Jest oczywiste, że odróżnienie między cierpieniem neurotycznym i cierpieniem prawdziwym nie jest takie latwe, ale jest jednak możliwe. Głównie trzeba brać pod uwagę funkcje owych odmiennych typów cierpienia. Neurotyk bowiem traktuje swoje cierpienie jako środek do osiągnięcia celów trudnych. Stąd K. Horney stwierdza, że „każde cierpienie neurotyczne podyktowane jest pragnieniem zadowolenia" ${ }^{16}$. Neurotyk szuka też w cierpieniu obrony przed grożącym niebezpieczeństwem — podejmując mniejsze cierpienie unika większego. Horney pisze: „Oskarżając siebie, neurotyk unika cudzych zarzutów i oskarża innych; sprawiając wrażenie chorego i głupiego, unika wymówek; dewaluując siebie, unika groźby współzawodnictwa, a cierpienie, które jednocześnie ściąga na siebie, jest zarazem środkiem obrony"17. Autorka tej wypowiedzi zastrzega się jednak, że cierpienie towarzyszące nerwicom, w większości przypadków nie ma nic wspólnego z pragnieniem cierpienia, ale wynika z wewnętrznych konfliktów. Rodzaje cierpienia neurotycznego, wynikające $\mathrm{z}$ wewnętrznych konfliktów, są znamienne. Wynikają one np. $\mathrm{z}$ doświadczenia rozbieżności między możliwościami i osiągnięciami, ze skłonności do obwiniania siebie itp.

Dość często także niejednoznacznie nazywa się cierpienie duchowe. Mówi się np. o tzw. cierpieniu moralnym, bólu duszy. Empiryczne dane wskazują, że przez cierpienie duchowe (moralne) rozumie się przede wszystkim dylematy moralne, odejście od wartości, zaniechanie trudu własnego istnienia. Cierpienie to zdaje się być mniej objęte terapią. Można powiedzieć, że skala cierpień

${ }^{14}$ R. W. Fairchild, Seelsorge mit depressiven Menschen, Mainz 1991, s. 26.

15 A. Moreno, Jung, bogowie i cztowiek wspótczesny, Warszawa 1973, s. 41; por. J. J a cobi, Psychologia C. G. Junga, Warszawa 1968, s. $162-163$.

${ }_{16}$ Neurotyczna osobowość naszych czasów, Warszawa 1982, s. 171.

17 Tamże, s. 172. 
duchowych jest rozleglejsza niż cierpienia fizycznego. Podobnie jak w innych rodzajach cierpienia, mieści się ono między dwoma krańcami, tj. przykrością i nieszczęściem. Nieszczęście oznacza szczególną kumulację cierpienia. Wówczas cierpienie zdecydowanie zdaje się być sytuacją graniczną.

Oprócz fundamentalnych podziałów cierpienia ludzkiego na takie, które jest: zawinione i niezawinione, sensowne lub bezsensowne, krótkotrwałe bądź długotrwałe (przewlekłe), błahe i dotkliwe, egzystencjalne (problematyzujące życie człowieka) i zwykłe (stanowiące problem, ale nie zderzające człowieka przede wszystkim z pytaniem o sens), mówi się też o rozmaitych cierpieniach ze względu na okoliczności, jakie je wyzwalają. Głównie chodzi tu o cierpienie konieczne (losowe) i niepotrzebne (zbędne). Każde z wyżej wymienionych rodzajów cierpienia może mieć w przeżyciach osoby znamiona losowości. Ogólnie do cierpień koniecznych zalicza się ból oraz lęk, ponieważ te dwa negatywne uczucia zabezpieczają czlowieka przed większymi niebezpieczeństwami, są swoistym systemem alarmowym. Cierpienie konieczne domaga się określonej odpowiedzi w postawie. Niekiedy łączy się ono z wyższą koniecznością moralną. Typowym przykkładem jest męczeństwo. Cierpieniem zbędnym jest zaś „wszelkie cierpienie dające się usunąć: za pomocą kuracji, terapeutycznie; albo też ominąć: przez zapobieganie chorobom, profilaktykę, higienę"18.

$\mathrm{Na}$ ogół psychologowie nie mają wątpliwości, że cierpienie jest zjawiskiem nieuchronnym w życiu człowieka. Np. Freud w eseju Kultura jako źródło cierpień wskazuje na trzy źródła cierpienia, tj. potęgę natury, kruchość ciała człowieka i niedoskonałość struktur organizacyjnych. Na temat dwóch pierwszych źródeł Freud nie rozpisuje się szerzej, uważając, że należy bezdyskusyjnie uznać ich nieuchronność. Organizm człowieka jest ograniczonym i przemijającym tworem, ale poznanie tego faktu nie powinno ludzi paraliżować, lecz nadawać kierunek działalności. Natomiast cierpienie mające swe źródła społeczne wynika z nieprzezwyciężalnych cech ludzkiej natury, których niepodobna zmienić przez właściwą organizację. Zastanawiając się nad tym, dlaczego stworzone przez człowieka formy organizacyjne w małym stopniu chronią od cierpienia i przynoszą szczęście, Freud podejrzewa, że wynika to z psychicznej istoty człowiekka. Niezależnie od tego jak krytyczny jest stosunek Freuda do kultury jako źródła cierpień człowieka uznaje on, że „wszystko, za pomocą czego staramy się obronić przed groźbą cierpienia, należy właśnie do tejże kultury"19.

18 V. E. Fra n k l, Psychoterapia dla każdego, Warszawa 1978, s. 125.

${ }^{19}$ Z. Fre ud, Cztowiek, kultura, religia, Warszawa 1967, s. 259. 


\section{FUNKCJE CIERPIENIA}

Sytuacje cierpienia tworzą złożony obraz psychologiczny, który można rozmaicie namalować w zależności od tego, jakie przyjmuje się kwalifikacje cierpienia, oraz jakie jest osobiste doświadczenie jednostki. Rozumiejąc cierpienie w kontekście transakcji, tzn. wzajemnego wpływu w czasie międzyosobowego spotkania na poziom emocjonalny, uczuciowy a także obiektywizację rzeczywistości możemy przyjąć, że wartościowanie i przeżywanie sytuacji cierpienia ma wymiar subiektywny, któremu towarzyszy miara intersubiektywna. A zatem to, czym jest cierpienie oraz z jaką nadzieją się łączy, stanowi psychologiczną rzeczywistość międzyosobową.

Każda sytuacja cierpienia zmusza do konfrontacji z zachowaniem się w sytuacji stresowej. Cała osoba musi podjąć wiążące się z nią określone napięcie. Sytuacje pełne cierpienia najlepiej są przepracowywane, kiedy osoba traktuje je jako wezwanie. Stąd wynika, że w sytuacji spotkania z osobą cierpiącą, oprócz nazwania tego, co się zdarza, trzeba jej wskazać coś korzystnego, możliwości rozwoju. Przez podjęcie tego wyzwania wzrasta poczucie własnej pewności i kompetencji w zakresie oceny własnej osoby (m.in. rozumienie możliwości zachowania się w sytuacjach specyficznych) ${ }^{20}$.

Niektórzy badacze uważają, że kryzys w zakresie autonomii człowieka współczesnego można interpretować jako przemiany w zakresie rozumienia cierpienia, zmierzające w zasadzie do wyeliminowania go z życia ludzkiego. Koncepcji jakby unicestwienia cierpienia towarzyszy ucieczka od cierpienia, unikanie, zaprzeczanie i maskowanie go. Cierpienie przeobraża się wtedy np. w projekcyjną nienawiść a zaprzeczanie jego faktu w histeryczne gry ${ }^{21}$.

Psychologicznie rzecz biorąc, cierpienie nie może być „traktowane ani jako dobro, ani jako zło, lecz jako warunek, który wyostrza wrażliwość duchową bądź inną" 22. Zdolność wykorzystania cierpienia raczej w kierunku pozytywnym niż negatywnym w znacznym stopniu zależy od zdolności jednostki do skupienia się na czymś, co jest poza cierpieniem. Niemniej niektórzy psychologowie zdają się zacieśniać doświadczenie cierpienia tylko do wymiaru negatywnego, np. J. Kozielecki pisze, że „cierpienie jest negatywnym stanem emocjonalnym, który destrukcyjnie wpływa na osobowość człowieka i obniża poziom jego funkcjonowania. Ten stan emocjonalny można sprowadzić do głębokiej, skrajnie przykrości trwającej na ogół dłuższy czas"23. E. Fromm zdaje się utożsamiać cierpienie z nieszczęściem, które przejawia się w zmniejszeniu witalno-

\footnotetext{
${ }^{20}$ Por. T. Le y n e r, Zum Ernst des Leidens, oder: Das Verführerische, eine Hoffnung zu „,haben”, „Lebendige Seelsorge” 1: 1988 s. 66 - 67.

${ }^{21}$ Por. H. E. Ri ch t e r, Der Gottes Komplex, Mainz 1990, s. 129-187.

${ }^{22}$ W. H. Clark, The Psychology of Religion, N. York 1958, s. 182. s. 241.

23 J. Kozielecki, O człowieku wielowymiarowym. Eseje psychologiczne, Warszawa 1988,
} 
ści, intensywności odczuwania i myślenia, produktywności ${ }^{24}$. Na ogół jednak panuje przekonanie, że cierpienie ma niezastąpione znaczenie w kształtowaniu człowieka w kierunku dojrzałości osobowej. Takiego zdania byli nie tylko filozofowie. Piszą o tym również współcześni psychologowie o orientacji humanistycznej. Maslow np. zauważa, że „pozbawienie ludzi możliwości przeżywania cierpień, nadmierne ochranianie ich przed nimi może się okazać nawet niekorzystne, gdyż z kolei jest wyrazem pewnego braku szacunku dla integralności, wrodzonej natury oraz przyszłego rozwoju jednostki" 25 . Cierpienie ma moc budowania człowieka, gdy wiąże się z pewnym trudem. Wtedy „z tych krwawych psychicznie zmagań, z tego pochylania się nad problemami transcendentalnymi, ale wymagającymi konkretów, rodzą się wyższe aspekty życia psychicznego, jak: empatia, pomoc innym, przeżywanie jedności przyjaźni i miłości, tęsknota do poznania sensu życia, do twórczości, do odkrywania i tworzenia innych niż zastane poziomy rzeczywistości"26. Jung nawet uważa, że wszelki postęp człowieka rodzi się z cierpienia duszy.

Jak wiadomo, cierpienie (wraz ze śmiercią i winą) może tworzyć neurotyczną triadę. Nie jest jednak sytuacją bezwyjściową. Ale też nie będąc samo w sobie wartością, cierpienie ma odniesienia do wartości, ponieważ umożliwia ich realizację. Taka szansa istnieje niezależnie od płci, wieku, wykształcenia, inteligencji, zawodu i wielu innych zmiennych. Innymi słowy graniczna sytuacja cierpienia staje się dla człowieka „egzaminem dojrzałości, experimentum crucis"27. Budzi też wrażliwość i urealnia poczucie śmiertelności ${ }^{28}$.

Cierpienie wydobywa nowe siły z człowieka, umożliwia koncentrację na tym, co najistotniejsze, stanowi wezwanie, jest jakby otwarte w tym sensie, że to człowiek musi mu nadać określony sens. W sposób najszerszy wymiary cierpienia człowieka ujmuje Jan Paweł II wychodząc poza formalne opisy i zwracając uwagę na to, co zasadnicze ze względu na rozmaite możliwości człowieka. Pisze On: „Cierpienie jest po to, aby wyzwalało miłość, ażeby rodziło uczynki miłości bliźniego, ażeby całą ludzką cywilizację przetwarzało w cywilizację miłości"29. Odnajdujemy w tych słowach zatem trzy istotne wymiary sensu cierpienia: indywidualny, interpersonalny i cywilizacyjny (ogólnokulturowy). Dzięki zdolności do ofiarowania własnego cierpienia, osoba ma bowiem możliwość zaświadczyć przez miłość i przez tę miłość się rozwinąć. Jest to indywidualny aspekt sensu życia człowieka. Zaś fakt cierpienia innej osoby stwarza okazje do podjęcia szeregu dobrych dzieł, które — podobnie jak każde autentyczne zaangażowanie się prospołeczne - jest sensorodne. Dlatego ewangeliczny

${ }^{24}$ Por. Man for Himself. An Inquiry into the Psychology of Ethics, N. York 1967, s. 185 - 186.

${ }^{25}$ A. H. Maslow, W stronę psychologii istnienia, Warszawa 1986, s. 17.

${ }^{26}$ K. D ą b r ow s ki, Wprowadzenie do higieny psychicznej, Warszawa 1979, s. 189; por. M.

Grzywak-Kaczyńsk a, Trud rozwoju, Warszawa 1988, . 26-27.

27 Homo patiens, s. 76.

${ }_{28}^{2}$ Por. H. H a sk ov cova, Między życiem a śmiercia, Warszawa 1978, s. 54.

${ }^{29} \mathrm{SD}, \mathrm{nr} 30$. 
czyn Dobrego Samarytanina stał się czytelnym przykładem interpersonalnego sensu cierpienia. Kulturotwórcze znaczenie cierpienia polega na tym, że właściwie przyjęte jako fakt społeczny zwraca ludzką uwagę na określone preferencje w zakresie wartościowania. Dzięki świadkom cierpienia może się kształtować opozycyjna w stosunku do tzw. cywilizacji śmierci — w rozmaity sposób negującej godność człowieka - cywilizacja miłości. Charakteryzuje się ona prostym choć trudnym w realizacji czwórmianem wezwań etycznych: osoba jest ważniejsza niż rzecz, należy bardziej być niż mieć, ważniejsze jest miłosierdzie niż sprawiedliwość, etyka musi iść przed techniką. Przestawienie powyższej hierarchii powoduje lekceważenie starego lub schorowanego człowieka, który jest wtedy postrzegany jako nic już nie znacząca materia, a technika (np. medyczna) usprawiedliwia wszelkie manipulacje życiem ludzkim.

W rozumowaniu Papieża na temat sensu cierpienia człowieka jest jeszcze jeden bardzo ważny akcent. Dotyczy on sformułowania pytania o sens cierpienia. Jest bowiem bardzo wyraźna różnica psychologiczno-religijna między pytaniem dlaczego cierpię? a pytaniem dla czego bądź dla kogo cierpię? W pierwszym przypadku bowiem zwracamy uwagę na genezę cierpienia, której dociec nie sposób: jest ono ostatecznie tajemnicą. Tutaj trzeba wspomnieć, że wiele kryzysów religijnych zawiązywało się właśnie dlatego, że ktoś pytał dlaczego istnieje cierpienie? Zaś pytanie: komu lub czemu mogę poświęcić cierpienie? ustawia człowieka perspektywicznie, zwraca uwagę na konieczną dla usensownienia cierpienia jego intencjonalność. Religijne perspektywy cierpienia dopełniają psychologiczny wymiar analiz i zarazem wskazują, że nauczanie Jana Pawła II - wywiedzione z egzystencjalnego doświadczenia własnego cierpienia a także cierpienia wielu osób, z którymi się spotyka - jest bardzo bliskie ujęciom logoterapeutycznym, zwłaszcza, gdy czytamy następujące słowa Frankla: „Jeśli w życiu coś posiada w ogóle znaczenie, to musi to być znaczenie cierpienia. Cierpienie jest częścią życia i nie może być wykorzenione, podobnie jak los i śmierć. Bez cierpienia i śmierci życie nie byłoby pełne. Sposób, w jaki człowiek przyjmuje swój los i wszystkie cierpienia, które on przynosi, sposób, w jaki bierze na siebie swój krzyż, daje mu nawet w najtrudniejszych okolicznościach szerokie możliwości nadania swemu życiu głębokiego znaczenia" 30 .

Cierpienie, w jakim człowiek uczestniczy i które może go tworzyć osobowościowo, pozostaje ostatecznie tajemnicą dla badaczy. Jednakże niepokój intelektualny i egzystencjalny, jaki ono budzi, motywuje do poszukiwania przybliżonej wiedzy o ludzkim trudzie istnienia. Jesteśmy zdani na szczególny brak obiektywizmu w analizie cierpienia i stąd tak wiele rozmaicie uwarunkowanych odniesień do niego. Postawy wobec cierpienia to jednak odrębny i szeroki problem psychologiczny, który zostanie przedstawiony w odrębnym opraco-

${ }^{30}$ V. E. Frankl, Man's Search for Meaning, N. York 1968, s. 106. 


\title{
waniu. Natomiast zadaniem artykułu było wyznaczenie zasadniczych kierun- ków psychologicznej penetracji granicznej sytuacji cierpienia.
}

\author{
PSYCHOLOGICAL ASPECTS OF SUFFERING
}

\section{Summary}

Man's common experience interpreted in the humanities points to the inevitability of suffering. Suffering was even termed a basic border situation (C. Jaspers). The so-called scientific psychology hardly analyses human suffering. S. Freud regarded culture as a cource of suffering and the behaviourists did not see the need for an analysis of man's inner experience. Radical change of the view on suffering was brought about in the works of V. E. Frankl who thought man to be homo patiens (to be a man means to suffer). There are various sources and kinds of suffering. Based on his own vast researches the author characterizes three kinds of man's suffering: physical (pain, somatic diseases), psychical (hardships, mental disorders and illnesses) and spiritual (lack of a meaningful life, moral dilemmas). He also puts forward a hypothesis that a psychic suffering is a correlative between both mental and spiritual sufferings. Suffering fulfills a variety of functions in the life and personality of a human being; it can cause a personality degradation or can further a personality development. Therefore, we can speak of the ambivalent character of suffering. The elementary psychological problem, encountered in suffering, is to give suffering some meaning. In order to do this one must ask about future: for whom and what (for what cause) do I suffer? Whereas the question about the ultimate origin of suffering (why do suffer?) not only makes it possible to explain the issue fully but first of all allows us to recognize suffering as a mystery of human existence. The author proves that the analyses carried out by John Paul II in Salvifici doloris are coherent with the principles of logotherapy. However, the analyses are more profound since they point to individual, social, cultural and transcendental dimensions of suffering. 